\title{
ABSENCIA KRIMINOLOGICKÝCH VÝSKUMOV PRI KREOVANÍ TRESTNEJ POLITIKY ŠTÁTU S AKCENTOM NA TREST DOMÁCEHO VÄZENIA ${ }^{1}$
}

\section{ABSENCE OF CRIMINOLOGICAL RESEARCH IN THE CREATION OF STATE CRIMINAL POLICY WITH AN ACCENT ON THE PUNISHMENT OF HOME ARREST}

\author{
Veronika Tóthová \\ Univerzita Pavla Jozefa Šafárika v Košiciach, Právnická fakulta \\ https://doi.org/10.33542/SIC2019-2-08
}

\begin{abstract}
ABSTRAKT
Autor sa včlánku venuje trestnej politike štátu a jej smerovaniu, ktorá sa prejavuje najmä $v$ zmenách platnej legislativy. Smerovanie trestnej politiky sa prejavilo aj v legislatívnom návrhu zmeny zákona č. 300/2005 Z. z. Trestný zákon v znení neskorších predpisov, najmä $v$ otázkach ukladania alternativneho trestu domáceho väzenia. Autor poukazuje na skutočnost', že táto zmena zákona nie je podporená žiadnym logickým argumentom, no najmä poukazuje na absenciu relevantných a hodnotných kriminologických výskumov, nakol'ko v Slovenskej republike nebol od dnešného dña zriadený Kriminologický ústav, ktorého podklady by $v$ konečnom dôsledku mohli viest' samotného zákonodarcu k rozdielnym záverom.
\end{abstract}

\begin{abstract}
In the article, the author deals with the criminal policy of the state and its direction, which is reflected mainly in the changes in the valid legislation. The direction of criminal policy was also reflected in the legislative proposal to amend Act no. 300/2005 Coll. Criminal Code, as amended, in particular on the imposition of an alternative punishment for home arrest. The author points out that this change in the law is not supported by any logical argument, but points out in particular the absence of relevant and valuable criminological research, since the Criminological Institute has not been established in the Slovak Republic from now on. different conclusions.
\end{abstract}

\section{I. ÚVOD}

Trestná politika štátu $\mathrm{v}$ najširšom slova zmysle zahŕňa činnost' všetkých článkov politického systému, ktorá sa zameriava na reguláciu všetkých sociálne patologických javov vrátane kriminality. Nárast kriminality v jej rôznych oblastiach vyvolal dynamické zmeny v trestnej politike štátu, čo prinieslo zamyslenie sa nad samotným účelom trestu, a jeho funkcií, ktoré v spoločnosti plní. Asi najväčšia pozornost' bola venovaná alternatívnemu

Predložený článok vznikol s podporou a je výstupom riešenia výskumného projektu APVV-16-0362 „Privatizácia trestného práva - hmotnoprávne, procesnoprávne, kriminologické a organizačno-technické aspekty“. 
modelu trestnej spravodlivosti - restoratívnej spravodlivosti, uplatňovaniu depenalizácie, a uplatňovaniu alternatívnych sankcií. Trestná politika štátu je súhrnom opatrení trestnoprávnej povahy, ktorými spoločnost' reaguje na kriminalitu. Ciel'om trestnej politiky je nielen kriminalitu kontrolovat', ale najmä vytvorit' vhodné riešenia $\mathrm{k}$ jej eliminácii a represii. V súčasnosti neexistuje exaktná definícia trestnej politiky ${ }^{2}$, čo potvrdzuje množstvo autorov vyjadrujúcich sa k tejto problematike. Ako uvádza Cejp M.: Východiskom pre trestnú politiku štátu je kriminálna politika ${ }^{3}$. Autor d'alej uvádza, že koncepcia kriminálnej politiky by mala vychádzat' zo serióznych podkladov. ${ }^{4}$ Za tieto podklady môžeme v prvom rade chápat' Ústavu Slovenskej republiky, platné zákony a iné normatívne právne akty. Ak je východiskom trestnej politiky kriminálna politika, logicky možno dospiet' k záveru, že ciel'om trestnej politiky bude sankčná politika. Tak ako aj kriminálna politika aj sankčná politika by mala vychádzat' nielen z vyššie uvedených serióznych podkladov, ale nemala by absentovat' dôležitost' jednak štatistických údajov, ale predovšetkým existencia kvalitných kriminologických výskumov, ktoré by mohli prispiet' ku kreovaniu trestnej politiky v nadväznosti na kriminálnu politiku a z nej vyplývajúcu sankčnú politiku. Poznatky o stave, štruktúre, dynamike a vývoji kriminality, vyplývajúce z kriminologických výskumov, môžu byt' vodítkom pre kreovanie trestnej politiky a jeho ciel'u - sankčnej politiky. Vzhl'adom k tomu, že v súčasnosti v Slovenskej republike absentuje existencia akéhokol'vek inštitútu pri procese tvorby kriminologických výskumov, ciel'om tohto článku bude poukázat', na skutočnost', že bez relevantných záverov vyplývajúcich z kriminologických výskumov, môže zákonodarca pri kreovaní sankčnej politiky dospiet' ku kontroverzným záverom. Vzhl'adom na skutočnost', že spoločensky diskutovanú tému modelu restoratívnej alebo obnovujúcej spravodlivosti ( $\mathrm{z}$ ang. restore - obnovit', navrátit' do pôvodného stavu), ktorej aplikácia významne súvisí so širším uplatňovaním alternatívnych trestov, sa autor zameral práve na alternatívny trest domáceho väzenia, ktorý od svojej existencie v zákone prešiel mnohými zmenami, pričom autor podrobil kritike navrhovanú zmenu Trestného zákona týkajúcu sa tohto alternatívneho trestu, nakol'ko vidí práve paralelu absencie kriminologických výskumov a nedokonalej právnej úpravy tohto trestu a snahy o jej opätovné zmeny.

Z návrhu na zriadenie inštitútu kriminológie Ministerstva spravodlivosti Slovenskej republiky ${ }^{5}$ vyplýva, že na zmeny v kvantite, v štruktúre a vo vplyve kriminality musí reagovat' primárne kriminálna politika štátu. Systematicky by však mala vychádzat' z permanentného výskumu kriminality a z výskumu efektívnosti represívnych a preventívnych stratégií jej kontroly, z čoho vyplýva, že miesto kriminologického výskumu je tu teda nezastupitel'né. Kriminologický inštitút bol založený v Československu v roku 1960, vtedy pod názvom Výskumný ústav kriminologický so sídlom v Prahe. V roku 1990 došlo k zmene názvu Výskumného ústavu kriminologického na Inštitút pre kriminológiu a sociálnu prevenciu, čo malo predovšetkým akcentovat' prevenciu ako efektívny nástroj kontroly kriminality a súčasne naznačit' previazanost' medzi kriminológiou ako teoretickou i empirickou disciplínou a prevenciou a trestnou politikou ako jej aplikovaným vyústením. 1. januára 1993 skončila

\footnotetext{
Pozn. autora: definície pozri napr.: KARABEC, Z. Poznámky k trestní politice; Kriminalistika; 2012; č. 1, s. 3. Rovnako porov.: JELÍNEK, J.: Současná trestní politika - co je nejdůležitejší ? In: Poškozený a obět' trestného činu z trestněprávního a kriminologického pohledu; PRAHA; LEGES; 2012; s. 12. 3, MADLIAK, J.: Kriminológia; Košice; ATOM COMPUTERS - Košice; 1998; s. 75, MUSIL, J.: Úloha trestní politiky při reformě trestního práva. Trestní právo; $1 / 1998 ;$ s. 3.

3 CEJP. M.: Úloha kriminologického výzkumu při koncipovaní kriminální politiky. In: Kriminológia ako súčast' trestnej politiky : pocta prof. PhDr. Květoňovi Holcrovi, DrSc. k 80. narodeninám. - Vydání první. - Praha : Leges, 2018. s. 22, ISBN 978-80-7502-279-0.

4 Tamtiež. s. 22.

5 Dostupné na: www.old.justice.sk/kop/pk/2008/pk08015_03.pdf.
} 
pre Slovenskú republiku federálna pôsobnost' tohto inštitútu. Od tohto momentu existovala $\mathrm{v}$ Slovenskej republike na pôde Rady vlády SR pre prevenciu kriminality sústavná snaha o zriadenie vedeckého pracoviska so zameraním na kriminológiu, avšak možno konštatovat', že do dnešného dňa neúspešne. Za najväčšiu snahu možno považovat' legislatívny návrh ministerstva spravodlivosti na zriadenie kriminologického inštitútu v roku 2008, ktorý plne korešpondoval so Stratégiou prevencie kriminality v Slovenskej republike na roky 2007-2010 schválenej uznesením vlády SR č. 681 z 15. augusta 2007. Inštitút kriminológie mal byt' výskumným a teoretickým pracoviskom medziodborového zamerania.

Z uvedeného vyplýva, že zameranie inštitútu kriminológie by malo smerovat' najmä na vedeckú činnost' a skúmaním prejavov a príčin kriminality a $s$ ňou súvisiacich sociálnopatologických javov a prognózovaním vývoja kriminality, d’alej výskumnou, študijnou a analytickou činnost'ou a v neposlednom rade otázkami trestnej a bezpečnostnej politiky a kontroly, kde by mali spadat' otázky účinnosti trestov, alternatívnych opatrení a trestov a odklonov $\mathrm{v}$ trestnom konaní. Uvedené zameranie $\mathrm{v}$ súčasnosti aspoň z časti supluje spoločnost' pre trestné právo a kriminológiu, ktoré je dobrovol'ným, nezávislým a neziskovým záujmovým združením fyzických a právnických osôb, medzi ktorého ciele patrí štúdium stavu a vývoja trestného práva doma aj $\mathrm{v}$ zahraničí, vrátane medzinárodného práva trestného, podpora inštitúcii a legislatívy v tejto oblasti za účelom väčšej účinnosti ochrany spoločnosti pri súčasnom rešpektovaní zásad humanizmu a l'udských práv a skúmanie stavu a vývoja kriminality, jej prevencie a kontroly. Spoločnost' pre trestné právo a kriminológiu je však občianskym združením registrovaným zo strany Ministerstva vnútra Slovenskej republiky, z čoho vyplýva, že nemá možnost' využitia financovania zo štátneho rozpočtu, respektíve využivat' i potenciálne doplnkové zdroje finančných prostriedkov na riešenie výskumných úloh z grantových agentúr, resp. od príslušných orgánov OSN a EÚ a pod, čo by viedlo k uskutočňovaniu rozsiahlych vedeckých výskumov.

\section{TRESTNÁ POLITIKA A TREST DOMÁCEHO VÄZENIA}

V odbornej literatúre je akceptovaný názor, že, trest domáceho väzenia by mal byt' alternatívou ku krátkodobému nepodmienečnému trestu odňatia slobody, ukladaný za menej závažnú trestnú činnost'. Z pohl'adu mnohosti ukladania alternatívnych trestov je však trest domáceho väzenia najmenej ukladaným alternatívnym trestom, čo vyplýva zo štatistík ministerstva spravodlivosti Slovenskej republiky ${ }^{6}$. V roku 2015 bol trest domáceho väzenia uložený celkovo v počte 18 krát a v roku 2016 v celkovom počte 23 krát, v roku 2017 v počte len 18 krát, v roku 2018 je možné badat' opätovný nárast jeho ukladania v počte 20 krát. Práve vyššie uvedené počty viedli laickú, ale najmä odbornú verejnost' k diskusii možnosti rozšírenia ukladania tohto alternatívneho trestu, a tým aj zefektívnenia využívania elektronického systému monitorovania osôb, spustený Ministerstvom spravodlivosti SR v roku 2013 ako projekt Elektronického systému monitoringu obvinených a odsúdených (d’alej aj „ESMO“), ktorý bol spolufinancovaný Európskou úniou z prostriedkov Európskeho fondu regionálneho rozvoja prostredníctvom Operačného programu „Informatizácia spoločnosti“.

Z kriminologického hl'adiska by bolo vhodné a účelné poznat' diapazón osôb, a to tak z pohl'adu veku ako aj pohlavia, sociálneho zázemia, ale tiež charakteru trestnej činnosti u ktorých by uložený trest domáceho väzenia splnil svoj účel. Účel trestu vo všeobecnosti je vymedzený v $\S 34$ ods. 1 Tr. zák., podl'a ktorého trest má zabezpečit' ochranu spoločnosti pred páchatel'om tým, že mu zabráni v páchaní d’alšej trestnej činnosti a vytvorí podmienky

\footnotetext{
6 Štatistiky dostupné na www.justice.gov.sk.
} 
na jeho výchovu k tomu, aby viedol riadny život a súčasne odradí iných od páchania trestných činov; trest zároveň vyjadruje morálne odsúdenie páchatel'a spoločnost'ou. V prípade trestu domáceho väzenia možno okrem všeobecného účelu trestu poukázat' aj na skutočnost', že kladie dôraz na nápravu páchatel'a, ked’že s výkonom tohto trestu sú spojené rôzne resocializačné programy zamerané na osobnost' páchatel'a. V rámci výkonu trestu domáceho väzenia môže totiž súd fakultatívne uložit' primerané obmedzenia a povinnosti upravené $\mathrm{v} \S$ 51 ods. 3 a ods. 4 Tr. zák., ktorých základným ciel'om je, aby páchatel' viedol riadny život; sú teda ukladané za účelom dosiahnutia ciel'ov individuálnej prevencie. ${ }^{7}$ Posudzovanie osobnosti páchatel'a tak hrá prím práve pri ukladaní trestu domáceho väzenia. V súčasnosti ustanovenie 53 ods. 1 Tr. zák. upravuje podmienky uloženia trestu domáceho väzenia, ktoré musia byt' splnené kumulatívne. Prvou podmienkou je, že samostatný trest domáceho väzenia môže byt' uložený len za prečiny. ${ }^{8}$ Súd pri ukladaní trestu domáceho väzenia musí vziat' do úvahy hodnotiace kritériá vzt’ahujúce sa na povahu a závažnost' spáchaného prečinu a taktiež samotného páchatel'a. Zo zákonnej dikcie $§ 53$ ods. 1 Tr. zák. vyplýva, že trest domáceho väzenia sa neukladá všetkým páchatel’om prečinu. Predmetné ustanovenie definuje požiadavky na posúdenie vhodnosti uloženia tohto trestu pre páchatel'a namiesto trestu odňatia slobody, a to s prihliadnutím na uvádzané okolnosti. Vo vzt'ahu k osobe páchatel'a by mal súd skúmat' predovšetkým jeho osobnost', možnosti resocializácie, jeho prechádzajúcu kriminálnu minulost', jeho rodinné či majetkové pomery (či má trvalé bydlisko, kde by trest vykonával), sociálne prostredie. ${ }^{9}$ Pri posudzovaní týchto kritérí by mali byt' k dispozícii údaje o d'alšej recidíve páchatel'a, ktorému bol už v minulosti uložený trest domáceho väzenia. Túto skutočnost' by však mal súd posudzovat' najmä s ohl'adom na osobu páchatel'a a v prípade recidívy opätovne tento trest neuložit', aj ked' to Trestným zákonom nie je nijako limitované pri ukladaní trestu domáceho väzenia.

Ďalším vhodným kriminologickým ukazovatel'om pri ukladaní trestu domáceho väzenia bola skutočnost', u kol'kých odsúdených, ktorým bol uložený trest domáceho väzenia, došlo v skutočnosti aj k realizácii a ukončeniu probácie, a teda u kol'kých odsúdených súd nemusel pristúpit' $\mathrm{k}$ premene tohto druhu trestu na nepodmienečný trest odňatia slobody, čo by v konečnom dôsledku mohlo vytvorit' skupinu trestných činov, charakterovo podobných, kde naozaj trest domáceho väzenia plní svoj účel.

V súčasnosti však Ministerstvo spravodlivosti nevedie štatistiky vyššie zmieneným smerom, a preto vytvorit' „,identikit“ osoby páchatel'a, u ktorej je vhodné a účelné trest domáceho väzenia uložit', či už z pohl'adu veku, pohlavia a charakteru trestnej činnosti, sa javí priam nemožné a ponechané výlučne na rozhodnutí súdu. Na stránkach ministerstva spravodlivosti Slovenskej republiky je možné vyčítat' nič nehovoriace štatistiky o počte pridelených a ukončených probácií $\mathrm{v}$ jednotlivých krajoch týkajúcich sa trestu domáceho väzenia napríklad za rok 2017. ${ }^{10}$

\begin{tabular}{|l|c|c|}
\hline KRAJ & počet pridelených probácií & počet ukončených probácií \\
\hline Bratislava & 2 & 2 \\
\hline
\end{tabular}

ROMŽA, S. a kol. 2018. Alternativne spôsoby výkonu trestov. Košice : Šafárik Press UPJŠ v Košiciach, 2018, 170 s., ISBN

$978-80-8152-653-4$.

8 Zákon č. 300/2005 Z. z. Trestný zákon v platnom znení (§53 ods. 1).

9 Tamtiež str.

10 Z uvedených štatistík, však nie je možné vyčítat', akým páchatel’om bol trest domáceho väzenia uložený, ani z pohl'adu veku, pohlavia, charakteru trestnej činnosti, a ani nie je možné zodpovedat' otázku, či výkon kontroly elektronickými prostriedkami, ktorý je obligatórnou súčast’ou trestu domáceho väzenia bol efektívny. 


\begin{tabular}{|l|c|c|}
\hline Trnava & 1 & 0 \\
\hline Trenčín & 0 & 0 \\
\hline Nitra & 0 & 1 \\
\hline Žilina & 0 & 5 \\
\hline Banská Bystrica & 11 & 6 \\
\hline Prešov & 1 & 1 \\
\hline Košice & 3 & 0 \\
\hline
\end{tabular}

Tu je možné súhlasit's Z. Karabcom, že restoratívnu spravodlivost' nemožno zatial' chápat' ako ucelený systém reakcie spoločnosti na trestnú činnost'; predstavuje skôr určitý paralelný systém popri klasickom modeli trestnej spravodlivosti. Predstavuje alternatívu, ktorú možno efektívne využit' za určitých podmienok - na určitý typ kriminality, určitého páchatel'a a okolnosti spáchania trestného činu. Aplikácia obnovujúcej spravodlivosti predpokladá, že sa páchatel' k svojmu činu priznal, ide o menej závažný čin, ktorý je možné vyrovnaním urovnat', ide o páchatel'a, u ktorého je kriminalita skôr mimoriadnym vybočením ako opakovaným správaním a príležitost' pre odčinenie ujmy má prevýchovný účinok. Je teda vhodným postupom najmä v prípade menej závažnej majetkovej kriminality, mladistvých páchatel'ov, prvopáchatel'ov a tých, ktorí sa $\mathrm{k}$ trestnému činu priznali a akceptujú tak svoje zavinenie. $^{11} \mathrm{~V}$ nadväznosti na uvedené, trest domáceho väzenia nepochybne kopíruje myšlienku restoratívnej justície, vzhl'adom na fakt, že odsúdený pri tomto druhu trestu nestráca svoje sociálne väzby a taktiež nedochádza k pretrhnutiu citových väzieb odsúdeného a predpoklad náhrady škody pre poškodeného sa stáva dosiahnutel’ným.

Súčasná právna úprava trestu domáceho väzenia zakotvená v $\$ 53$ a nasl. Trestného zákona č. 300/2005 Z. z. v jeho platnom znení, sa javí prinajmenšom ako primeraná, ked' zákonodarca ustanovil v $\S 53$ ods. 1 Tr. zák., podl’a ktorého trest domáceho väzenia až na dva roky môže súd uložit' páchatel'ovi prečinu. Z § 34 ods. 6 Tr. zák., druhá veta, podl'a ktorého za trestný čin, ktorého horná hranica trestnej sadzby trestu odňatia slobody ustanovená v osobitnej časti zákona prevyšuje pät' rokov, musí súd uložit' trest odňatia slobody, čím zákonodarca obmedzil ukladanie trestu domáceho väzenia len na kategóriu trestného činu prečinu s hornou hranicou trestnej sadzby neprevyšujúcou pät' rokov. ${ }^{12}$ Pri tejto zákonnej formulácii sa prejavila základná funkcia trestného práva - ochranná funkcia, nakol'ko len u prečinov sa stretávame $\mathrm{s}$ tzv. materiálnym korektívom. ${ }^{13}$ ktorý vedie k posudzovaniu závažnosti konkrétneho prečinu. Skúmanie závažnosti má osobitný význam práve u prečinov, nakol'ko dáva možnost' súdu posúdit' niekedy vel'mi tenkú hranicu medzi priestupkom a prečinom.

Viacerí odborníci apelovali z dôvodu vyt'aženosti slovenských väzníc a to tak po stránke ekonomickej ako aj personálnej, na zmenu možnosti ukladania trestu domáceho väzenia aj pri kategóriách prečinov spáchaných $\mathrm{z}$ nedbanlivosti, s hornou hranicou prevyšujúcou pät' rokov. ${ }^{14}$ Táto situácia by značne riešila aj možnosti rozšírenia využitia kontroly

\footnotetext{
KARABEC, Z., 2003: Jaká je budoucnost trestní justice? Trestní právo, č. 3, s. 2-4 (prvá čast')a č. 4, s. 9-16 (druhá čast').

Bližšie pozri § 53 ods. 1 Trestného zákona a $§ 34$ ods. 6 Trestného zákona č. 300/2005 Z. z. v jeho platnom znení.

$\S 10$ ods. 2 zákona č. 300/2005 Z. z. Trestný zákon:“ Nejde o prečin, ak vzhl'adom na spôsob vykonania činu a jeho následky, okolnosti, za ktorých bol čin spáchaný, mieru zavinenia a pohnútku páchatel’a je jeho závažnost' nepatrná.“

14 KLATIK, J : Posilnenie ochrany obetí domáceho násilia elektronickým monitoringom osôb. In: Kriminologické možnosti riešenia domáceho násilia. Bratislava: Wolters Kluwer, 2017, ISBN: ISBN 978-80-8168-708-2.
} 
elektronickými prostriedkami - programu ESMO, ktorý je imanentnou súčast'ou trestu domáceho väzenia, a v súčasnosti má sledovaciu kapacitu až 2000 osôb ročne.

Ministerstvo spravodlivosti Slovenskej republiky, myšlienku rozšírenia právnej úpravy využitia technických prostriedkov pri kontrole výkonu niektorých rozhodnutí vydaných $\mathrm{v}$ trestnom konaní vrátane podpory využívania alternatívnych trestov - trestu domáceho väzenia posunulo do takej miery, že na 152. schôdzi vlády Slovenskej republiky predložilo návrh zákona, ktorým sa mení a dopĺn̆a zákon č. 300/2005 Z. z. Trestný zákon v znení neskorších predpisov. ${ }^{15}$, čím sa logicky zmenila aj hmotnoprávna úprava trestu domáceho väzenia. ${ }^{16}$ Zákonodarca tak zasiahol do zásady upravenej $\mathrm{v} \S 34$ ods. 6 trestného zákona, tak že ju modifikoval slovným spojením, ,ak tento zákon neustanovuje inak“, čím zrejme narážal práve na podmienky upravujúce ukladania trestu domáceho väzenia a to tým, že ustanovil, že trest domáceho väzenia je možné uložit' až na štyri roky a aj za trestné činy, a to viazaním na hornú sadzbu trestu odňatia slobody uvedenej v osobitnej časti, ktorá nesmie prevyšovat' 10 rokov. Podl'a navrhovaného znenia v pôvodnom $\S 53$ ods. 1 Trestného zákona sa tak slovo prečin nahradí slovom trestný čin a vloží sa nový ods. 2 ktorý znie:

„Súd môže uložit’ trest domáceho väzenia vo výmere podl'a odseku 1 za trestný čin s hornou hranicou trestnej sadzby ustanovenej týmto zákonom neprevyšujúcou desat' rokov, najmenej však na dolnej hranici trestnej sadzby trestu odňatia slobody ustanovenej týmto zákonom. “.

Za použitia gramatického výkladu normatívneho znenia $\S 10$ a $\S 11$ Trestného zákona, je tak možné vyvodit' záver, že trest domáceho väzenia bude možné uložit' tak za prečiny, vrátane prečinov s hornou hranicou prevyšujúcou pät' rokov, ako aj určenú kategóriu zločinov. Uvedené bude mat' za následok, že súd pri ukladaní trestu domáceho väzenia za trestný čin bude limitovaný dížkou trestu odňatia slobody, ktorý by mohol za daný skutok uložit' (najmä jeho spodnej hranice) s prihliadnutím na maximálnu dížka trestu domáceho väzenia vo výmere štyri roky. V zmysle predloženého návrhu bude teda možnost' ukladat' trest domáceho väzenia za všetky trestné činy, vrátane prečinov spáchaných z nedbanlivosti, ktorých horná hranice prevyšuje pät' rokov a zločinov, s hornou sadzbou trestu odňatia slobody neprevyšujúcou 10 rokov, ak pôjde o skutok, ktorý možno podl'a Trestného zákona potrestat' trestom odňatia slobody neprevyšujúcom 4 roky (t. j. aj s použitím ustanovení o možnosti zníženia dolnej hranice trestnej sadzby, napríklad mimoriadne zníženie trestu podl'a § 39). Je zrejmé, že navrhovanou právnou úpravou sa vel'mi progresívnym spôsobom upravili možnosti ukladania trestu domáceho väzenia, čím naznačil smerovanie trestnej politiky štátu, nakol'ko do kategórie trestných činov s hornou hranicou trestnej sadzby ustanovenej týmto zákonom neprevyšujúcou desat' rokov, spadajú aj trestné činy z hl'adiska závažnosti označované ako zločiny, vrátane prečinov spáchaných s nedbanlivosti, ktorých horná hranica prevyšuje pät' rokov, u ktorých trest domáceho väzenia vzhl'adom na obmedzenie ustanovené $v$ § 34 ods. 6 Trestného zákona doposial' nebolo možné. V dôvodovej správe je navrhovaná právna úprava odôvodnená najmä skutočnost'ou, že $\mathrm{v}$ súčasnosti $\mathrm{v}$ rozhodovacej činnosti súdov neevidujeme žiadne významné rozhodnutie, ktoré by predstavovalo prelom v nazeraní na ukladanie alternatívnych trestov. Naopak v dôvodovej správe sa uvádza, že Ústavný súd Českej republiky svojim nálezom sp. zn. II. ÚS 2027/17 vniesol nový pohl'ad na ukladanie trestov a predovšetkým na využitie alternatívnych trestov v zmysle aplikácie zásady „ultima ratio“. Uvedená argumentácia však nekorešponduje

\footnotetext{
15 Dôvodová správa prístupná na: https://rokovania.gov.sk/RVL/Material/23719/1.

16 Účinnost' predkladanej právnej úpravy sa navrhuje od 1. augusta 2019.

17 Nález dostupný na: www.usoud.cz.
} 
s možnost'ou rozšírenia ukladania trestu domáceho väzenia za zločiny, nakol'ko citovaný nález sa týka nedbanlivostného trestného činu usmrtenia. ${ }^{18}$ Uvedená argumentácia by svedčila v možnosti rozšírenia ukladania trestu domáceho väzenia za prečiny spáchané z nedbanlivosti, ktorých horná hranica by prevyšovala pät' rokov, čo by demonštrovalo možnosti využitel'nosti trestu domáceho väzenia aj pri trestných činoch, ktoré sa vyznačujú svojou vyššou závažnost'ou.

Otázkou ostáva, či pri schválení navrhovanej zmeny bude skutočne trest domáceho väzenia alternatívnym trestom $\mathrm{k}$ trestu odňatia slobody v naznačených medziach restoratívnej justície, tak ako to bolo aj historicky dané a teda ako alternatívny trest ku krátkodobému trestu odňatia slobody. Skôr sa prikláňame k argumentu, že trest domáceho väzenia, aj s prihliadnutím na maximálnu možnú výmeru jeho uloženia až na štyri roky, a možnost'ou ukladat' ho za vymedzenú kategóriu zločinu, bude skôr alternatívou k výkonu trestu odňatia slobody. V prospech tejto argumentácie svedčí aj samotný fakt uvedený v dôvodovej správe, kde sa uvádza, že ak súd nebude chciet' podmienečne odložit' výkon trestu, vyvstane mu tak d'alšia možnost' v podobe uloženia trestu domáceho väzenia. ${ }^{19}$

Pri možnosti uloženia trestu domáceho väzenia za zločiny vyvstáva tiež otázka potreby posudzovania osoby páchatel'a a závažnosti spáchaného trestného činu, vzhl'adom na fakt, že vyhodnotenie závažnosti zločinu ako nepatrnej alebo malej, tak ako je to pri prečinoch Trestný zákon nepripúšsta. Podmienka uloženia trestu domáceho väzenia uvedeného v $\S 53$ ods. 1 písm. a) - posudzovanie povahy a závažnosti trestného činu, v nadväznosti na uvedené stráca akoby svoj význam. Je otázkou, či si takýto páchatel' zaslúži alternatívny trest, a či si v skutočnosti splní svoj účel. Naznačeným možnostiam ukladania trestu domáceho za zločiny by sa však v konečnom dôsledku mohla vyriešit' paradigma ukladania trestu domáceho väzenia za trestné činy, ktoré spadajú z kriminologického hl'adiska do kategórie domáceho násilia. ${ }^{20}$ Príkladom by mohol byt' trestný čin týrania blízkej a zverenej osoby, ktorý spadá do kategórie trestného činu domáceho násilia, je zločinom s hornou hranicou nepresahujúcou desat' rokov, a pri splnení podmienky v $\S 53$ ods. 1 písm. c) trestného zákona, podl’a ktorého páchatel' dá písomný sl'ub, že sa bude zdržiavat' v obydlí na určenej adrese, ktorá nemusí byt' zhodná s adresou, kde dochádzalo k domácemu násiliu, a teda obete tohto trestného činu nebudú bezprostredne ohrozené, by tak súdu nič nebránilo tento trest uložit'.

18 Prípad otca, ktorý pod vplyvom alkoholu zapríčinil dopravnú nehodu, pri ktorej zomrela jeho manželka a jeden z dvoch synov. Okresný súd v tejto veci uložil trest zákazu vedenia motorového vozidla, zaviazal odsúdeného k náhrade škody, ktorá vznikla a uložil mu trest domáceho väzenia vo výmere 2 roky. V rozsudku toto svoje rozhodnutie odôvodnil predovšetkým tým, že páchatel' doposial' viedol usporiadaný život a prihliadol tiež na členov širšej komunity, v rámci ktorej rodina žila (učitel'ka v materskej škôlke, kde chodil syn páchatel'a, farára v rámci farnosti, zamestnávatel'a, susedov) a v neposlednom rade zdôraznil aj fixáciu maloletého syna na svojho otca. Krajský súd na základe odvolania prokurátora zrušil výrok o treste a páchatel'ovi uložit' nepodmienečný trest odňatia slobody na 4 roky. Vo svojom odôvodnení sa opieral predovšetkým o vysokú škodlivost' konania páchatel'a, pri ktorom zomreli dvaja l'udia a zastával názor, že na danej skutočnosti nič nemení ani množstvo pozitívnych ohlasov z prostredia komunity, v ktorej páchatel' žije. Jeho prípad nakoniec posudzoval Ústavný súd Českej republiky, ktorý vyhovel st’ažnosti st’ažovatel’a opierajúc sa o čl. 36 ods. 1 Listiny základných práv a slobôd (právo na spravodlivý proces) a čl. 6 ods. 1 Dohovoru o ochrane l’udských práv a slobôd. Zaviazal pritom Krajský súd, aby s ohl'adom na zvolené účely adekvátne odôvodnil priemeranost' uloženého trestu v súlade s princípy proporcionality a subsidiarity prísnejšej trestnej represie (ultima ratio).

19 V dôvodovej správe je uvedené: „Týmto návrhom sa vypíňa priestor medzi možnost’ou uloženia nepodmienečného trestu odňatia slobody a podmienečného odkladu výkonu takéhoto trestu. Súdu sa tak vytvára možnost' uložit' d’alší druh sankcie, ak je to $\mathrm{v}$ danom prípade účelné, vhodné a primerané v súlade s požiadavkami na individualizáciu trestu pre daného páchatel'a.“

20 Zákon č. 274/2017 Z. z. o obetiach trestných činov a o zmene a doplnení niektorých zákonov v § 2 ods. 1 písm. e) uvádza legálnu definíciu domáceho násilia. V zmysle uvedenej definície sa za trestný čin domáceho násilia považuje trestný čin, ktorý bol spáchaný násilím alebo hrozbou násilia na príbuznom v priamom rade, osvojitel’ovi, osvojencovi, súrodencovi, manželovi, bývalom manželovi, druhovi, bývalom druhovi, rodičovi spoločného diet’ata alebo inej osobe, ktorá s páchatel'om žije alebo žila v spoločnej domácnosti. 
Zaujímavost'ou ostáva, že navrhovaná legislatívna zmena sa v nijakom ohl'ade nedotýka $\S$ 65a Trestného zákona, ktorý upravuje tzv. back - end typ trestu domáceho väzenia, to znamená ked' dochádza k premene zvyšku trestu odňatia slobody na trest domáceho väzenia. Je nelogické, aby trest domáceho väzenia vo forme front - end typu by bolo možné uložit' za zločiny, ale jeho premena zvyšku trestu odňatia slobody na trest domáceho väzenia v prípade zločinov by už možný nebol, nakol'ko trestný zákon v $\S 65$ a Trestného zákona používa výlučne pojem prečin. Významným argumentom za zrušenie tohto obmedzenia, aj bez zmeny uskutočnenej vo vzt'ahu k závažnosti trestného činu je skutočnost', že nie je dôvod, aby bola vylúčená premena $\mathrm{v}$ prípadoch zločinov, ak osoba odsúdená za zločin môže byt' podmienečne prepustená. Uvedené platí o to viac, že pri premene sa osoba neocitá na slobode bez obmedzení, ale nad'alej podlieha obmedzeniam v podobe pevného denného harmonogramu a elektronického monitorovania. ${ }^{21}$ Možnost’ou pri schválení zmeny uloženia trestu domáceho väzenia v trvaní až na štyri roky a taktiež na kategóriu zločinov by bola zhojená momentálne hrozba uloženia nezákonného trestu pri premene zvyšku trestu odňatia slobody na trest domáceho väzenia, nakol'ko v §65a Tr. zák. sú pomerne konkrétne formulované podmienky, kedy môže súd pristúpit' k premene zvyšku trestu odňatia slobody na trest domáceho väzenia. Súčasné normatívne znenie citované pod písmenom c) v $§ 65 \mathrm{a}$ ods. 2 Tr. zák, ustanovuje, kedy sa premieňa zvyšok nevykonaného trestu odňatia slobody - v prípade ak zvyšok nevykonaného trestu odňatia slobody nepresahuje tri roky. ${ }^{22}$, čo predstavuje jednu $\mathrm{z}$ podmienok pri premenu nepodmienečného trestu odňatia slobody na trest domáceho väzenia. Za súčasnej maximálnej možnej dížky uloženia trestu domáceho väzenia ustanovenej v $§ 53$ ods. 1 Trestného zákona - až na dva roky a pri premene trestu podl'a znenia $\S 53$ ods. 5 Trestného zákona, kedy dochádza k premene trestu odňatia slobody na trest domáceho väzenia $\mathrm{v}$ súlade so zákonom stanoveným pomerom $1: 1$, rezultátom premeny by bol trest domáceho väzenia vo výmere 3 rokov, čo je mimo maximálnu možnú výmeru trestu domáceho väzenia.

\section{ZÁVER}

Za najvýznamnejší a neopomenutel'ný fakt považujeme skutočnost', že navrhovaná legislatívna zmena nie je podporená, žiadnym kriminologickým výskumom, čo spôsobuje aj jej slabé stránky a chyby, na ktoré sme poukázali. Tu je možné upriamit' pozornost', že ani dôvodová správa, ktorá by mala byt' vodítkom a reálnym vysvetlením navrhovaných zmien neobsahuje ani len náznak premís a dôvodov, ktoré by viedli k navrhovaným zmenám. Ak aj obsahuje nejaké ekonomické a iné ukazovatele, máme za to, že sa nijakým relevantným spôsobom nevysporiadala s dôvodmi možnosti ukladania trestu domáceho väzenia aj za kategóriu trestných činov - zločinov, a z toho dôvodu je možné ju označit' za „l'ubovôl'u“". $\mathrm{V}$ prípade existencie kriminologického inštitútu, po zavedení elektronického monitoringu ${ }^{23}$ by mal byt' výskum zameraný na využitie kapacity, nastavenia a spolupráce zainteresovaných subjektov a najmä identifikácie jeho slabých miest a zmysluplného rozširovania možnosti jeho využitia v Slovenskej republike, čím by bola podporená aj možnost' rozširovania ukladania alternatívnych trestov, vzhl'adom $\mathrm{k}$ tomu, že za relevantné ukazovatele, nie je

21 BELEŠ, A.,: Problematika premien trestu odňatia slobody na trest domáceho väzenia, In: Trestné sankcie: Progresívne trendy vo výkone trestných sankcií, Zborník príspevkov z 13. sekcie medzinárodnej vedeckej konferencie Bratislavské právnické fórum 2016, ISBN: 978-80-7160-437-2.

22 Bližšie pozri § 65a ods. 2 písm.) c Trestného zákona č. 300/2005 Z. z. v platnom znení.

23 Prijatie zákona č. 75/2015 Z. z. o kontrole výkonu niektorých rozhodnutí technickými prostriedkami a o zmene doplnení niektorých zákonov bolo výsledkom projektu ESMO, ktorého realizácia sa začala 28. apríla 2014 pod záštitou Ministerstva spravodlivosti Slovenskej republiky. 
možné považovat' počty ukladaných trestov. Bolo by potrebné taktiež zamerat' sa na štatistické ukazovatele vedúce $\mathrm{k}$ záverom, u akých páchatel'ov a pri akom druhu trestnej činnosti je naozaj trest domáceho väzenia možné považovat' za efektívny a plniaci svoj účel. Ďalej by bolo potrebné zamerat' sa na prácu probačných a mediačných úradníkov, ktorí zohrávajú významnú úlohu pri ukladaní alternatívnych trestov, najmä trestu domáceho väzenia. Ich činnost', ktorá vyúst'uje do vypracovania správy pre súd, totiž smeruje ku zisteniu dôležitých okolností pre uloženie tohto druhu trestu, to znamená aktuálnych bytových a sociálnych pomerov páchatel'a, prípadne d'alších okolností, ktoré majú na prípadné uloženie trestu domáceho väzenia podstatný vplyv. Tieto kriminologické výskumy, by v konečnom dôsledku mohli priniest' závery, ktoré by nepotrebovali žiadnu zmenu zákona a rozširovania možností kontroly technickými prostriedkami a tým ukladania alternatívnych trestov bez relevantných záverov, avšak ukázali by potrebu posilnenia pozícií probačnej služby, ktorá je v súčasnosti na vel'mi nízkej úrovni. ${ }^{24}$

\section{KLÚČOVÉ SLOVÁ}

Kriminalita, kriminologický ústav, alternatívne tresty, trest domáceho väzenia

\section{KEY WORDS}

Criminality, criminological institute, alternative punishments, home arrest

\section{POUŽITÁ LITERATÚRA}

1. JELÍNEK, J.: Současná trestní politika - co je nejdůležitejší ? In: Poškozený a obět’ trestného činu z trestněprávního a kriminologického pohledu; PRAHA; LEGES; 2012.

2. KARABEC, Z. Poznámky k trestní politice; Kriminalistika; 2012; č. 1.

3. MADLIAK, J.: Kriminológia; Košice; ATOM COMPUTERS - Košice; 1998.

4. MUSIL, J.: Úloha trestní politiky při reformě trestního práva. Trestní právo; 1/1998.

5. CEJP. M.: Úloha kriminologického výzkumu při koncipovaní kriminální politiky. In: Kriminológia ako súčast' trestnej politiky : pocta prof. PhDr. Květoňovi Holcrovi, DrSc. k 80. narodeninám. - Vydání první. - Praha : Leges, 2018. s. 22, ISBN 978-80-7502-2790 .

6. ROMŽA, S. a kol. 2018. Alternatívne spôsoby výkonu trestov. Košice : Šafárik Press UPJŠ v Košiciach, 2018, 170 s., ISBN 978 - 80- 8152 - 653 - 4.

7. KARABEC, Z., 2003: Jaká je budoucnost trestní justice? Trestní právo, č. 3, s. 2-4 (prvá čast')a č. 4, s. 9-16 (druhá čast').

8. KLATIK, J : Posilnenie ochrany obetí domáceho násilia elektronickým monitoringom osôb. In: Kriminologické možnosti riešenia domáceho násilia. Bratislava: Wolters Kluwer, 2017, ISBN 978-80-8168-708-2.

9. Nález Ústavného súdu Českej republiky sp. zn. II. ÚS 2027/17.

10. Beleš, A.,: Problematika premien trestu odňatia slobody na trest domáceho väzenia, In: Trestné sankcie: Progresívne trendy vo výkone trestných sankcií, Zborník príspevkov z 13. sekcie medzinárodnej vedeckej konferencie Bratislavské právnické fórum 2016, ISBN 978-80-7160-437-2.

24 Tu však narážame na d’alšie aplikačné problémy a to personálneho charakteru, nakol'ko v súčasnosti pôsobí na poste probačného a mediačného úradníka na jednotlivých súdoch v rámci Slovenskej republiky len 98 osôb. 
11. Zákon č. 274/2017 Z. z. o obetiach trestných činov a o zmene a doplnení niektorých zákonov.

12. Ústava č. 460/1992 Zb. Ústava Slovenskej republiky.

13. Zákon č. 300/2005 Z. z. Trestný zákon.

14. Zákon č. 301/2005 Z. z. Trestný poriadok.

15. zákon č. $75 / 2015$ Z. z. o kontrole výkonu niektorých rozhodnutí technickými prostriedkami a o zmene doplnení niektorých zákonov.

16. www.usoud.cz.

17. www.justice.gov.sk.

18. Dôvodová správa k návrhu zákona, ktorým sa mení a doplńa zákon č. 300/2005 Z. z. Trestný zákon $\mathrm{v}$ znení neskorších predpisov prístupná na: https://rokovania.gov.sk/RVL/Material/23719/1.

19. Vlastný materiál k návrhu zákona, ktorým sa mení a dopĺn̆a zákon č. 300/2005 Z. z. Trestný zákon v znení neskorších predpisov dostupný na:

https://rokovania.gov.sk/RVL/Material/23719/1.

\section{KONTAKTNÉ ÚDAJE AUTORA}

JUDr. Veronika Tóthová, PhD.

Odborný asistent, Katedra trestného práva

Právnická fakulta Univerzity Pavla Jozefa Šafárika

Kováčska 30, 04001 Košice

e-mail: veronika.perdukova@upjs.sk

Telefón: 055/234 4146 